\title{
SPIKE CURB OF MENTAL HEALTH DISORDERS: AN ALTERNATIVE MENTAL HEALTH STRENGHTENING PROGRAM IN DEPOK, WEST JAVA
}

\author{
Ernisfi', Yaslis Ilyas' ${ }^{1}$, Zakiah $^{2}$ \\ 1)Faculty of Public Health, Universitas Indonesia \\ ${ }^{2}$ Municipality Health Office, Depok
}

\begin{abstract}
Background: Indonesia has the highest rate of years of life lost to disability or early death due to schizophrenia. More than 90\% of people with mental illness do not get any treatment and tens of thousands of people with psychosis are illegally detained in the family home. Government, a core part of the recent World Health Organization global strategy, has the potential to address these challenges. The aim of the study was to investigate an alternative mental health strengthening program in Depok, West Java.

Subjects and Method: This was a descriptive study conducted in Depok, West Java. A sample of municipality office personnel was selected for this study. The data were collected by in depth-interview. Input data (man, money, material, method, and machine), process data management, and outcome data were obtained from document review.

Results: Mental health strengthening program had not been carried out optimally. Mental health strengthening program in Depok started from the top level multi sectorial coordination, with city mayor took the central figure. Mental health program included "unite, find, heal and empower". It became an alternative mental health strengthening program.
\end{abstract}

Conclusion: Mental health strengthening program has not carried out optimally. Strengthening program includes "unite, find, heal and empower" are underexplored.

Keywords: mental health, strengthening program, unites, find, heal, empower

\section{Correspondence:}

Ernisfi. Faculty of Public Health, Universitas Indonesia.

Email: Ernis120876@gmail.com. Mobile: 087880055728.

\section{BACKGROUND}

$\overline{\text { Severe mental disorders pose a burden }}$ to the government, family and society because the patient's productivity decreases and ultimately creates a large burden on patients and families. From the government's point of view, this disruption spends huge costs on health services. In the implementation of mental health efforts, the role of the government must be present to realize the highest degree of public health, not only physically healthy, but also mentally, emotionally and socially healthy in accordance with the provisions of
Law No. 18 of 2014 concerning Mental Health (Republic of Indonesia, 2014).

The prevalence of mental disorders from year to year is increasing, both severe mental disorders and emotional disorders. In Depok, assuming a population of around 2.1 million, it is estimated that there are 3,253 people with severe mental disorders, 348 people who have been in shackle and there are 132,358 who have experienced emotional mental disorders. Based on the data obtained by Depok City Health Profile in 2016, only 1,687 visits of patients with severe mental disorders 
and data on unreported emotional mental disorders were not reported (Health Office Depok, 2018).

Health Development is currently still focused on being physically healthy, but mentally, spiritually and socially healthy are still neglected. The World Health Organization (WHO) is defined as a state of well-being that includes physical, mental and social conditions that are not only free from illness or disability. 1945 Constitution of the Republic of Indonesia guarantees that everyone can live physically and spiritually as well as obtain health services by administering health development. The health development goal that is to be achieved is the realization of the highest degree of health. To achieve this goal, it is necessary to do various health efforts including mental health efforts with a promotive, preventive, curative and rehabilitative approach. Mental Health Efforts must be carried out in an integrated, comprehensive and sustainable manner by the Government, Regional Government, and / or community (Ministry of Health, 2015).

Mental Health Services for everyone and guarantee of the rights of People with Problems with the Ministry of Religion (ODMK) and People with Mental Disorders (ODGJ) cannot be realized optimally. ODMK and ODGJ rights are often overlooked, both socially and legally. Socially, there is still stigma in the community so that families hide the existence of family members suffering from mental disorders (WHO, 2011, 2014b, 2014a). This has led to limited access of ODMK and ODGJ to health services. Whereas legally, the existing legislation has not been comprehensive so that it hampers the fulfillment of ODMK and ODGJ rights. In addition, the un-optimal
Mental Health services indirectly affect the success rate of health development. Most ODGJs experience a decline in physical health which ultimately lowers productivity, both at work and in their daily activities. Overall Mental Health disorders affect the Indonesian Human Development Index (HDI) and increase the social budget burden for public health (Dewi, 2012).

In 2000 , data on mental disorders was $12 \%$, in 2001 it increased to $13 \%$ and is predicted to be $15 \%$ in 2020 (1). 2001 World Health Report (WHO) states that neuropsychiatric disorders are a contributor to one-third of disabilities as assessed by the disability of adjusted life years (DALYs) (2). In Indonesia, mental disorders continue to increase both in number and type. Based on the report of the results of Basic Health Research (Riskesdas), 2013, the prevalence of emotional mental disorders in Indonesian population aged $>15$ years is $6 \%$. The prevalence in West Java Province is 9.3\% and Depok is $12 \%$ and the prevalence of severe mental disorders in the Indonesian population is 1.6 per mile. The prevalence in West Java is $\mathbf{1 . 6}$ per mile and in Kota Depok 0.6 per mile. Of this number $10.7 \%$ in urban areas and $18.2 \%$ in rural areas have been installed. The assumption of the population in Depok City is around 2.1 million, so it is estimated that there are 3,253 people with severe mental disorders, 348 people who have ever been sold and there are 132,358 people who have experienced mental emotional disorders. Recorded from the Depok City Health Office monthly mental health report only 1,687 visits of patients with severe mental disorders and data on mental emotional disorders were not reported (Ministry of Health, 2013). 
Mental emotional disorders are disorders that can be experienced by everyone in certain circumstances, but can recover completely. This disorder can continue to be a more serious disorder if it is not successfully addressed (Siswanto, 2007). Mental emotional disorders are expected not to develop into more serious mental disorders if people who experience it can cope with or treat as early as possible to the health care center or seek treatment competent health personnel. When mental emotional disorders become severe mental disorders, it creates a burden on the government, family and society because the patient's productivity decreases and ultimately creates a large burden on patients and families. From the government's point of view, this disruption spends huge costs on health services. WHO states 10 major health problems that cause disability, 5 of which are mental health problems namely depression, alcoholism, bipolar disorder, schizophrenia and obsessive compulsive disorder (WHO, 2013, 2014a).

Until now there is still a mistreatment in patients with severe mental disorders in Indonesia. This is due to treatment and access to mental health services is inadequate. Health financing for ODGJ in Depok City ranks first in the last 4 years, meaning that ODGJ's medical expenses take the largest portion in the budget allocation for Depok City (City Health Office Depok, 2016).

The issuance of Law No. 18 of 2014 concerning Mental Health is intended to ensure that everyone can achieve a good quality of life, enjoy a healthy mentality, free from fears, stresses, and other disorders that can interfere with Mental Health; guarantee everyone can develop intelligence potential; provide protection and guarantee Mental Health services for ODMK and ODGJ based on human rights; provide integrated, comprehensive and sustainable health services through promotive, preventive, curative and rehabilitative efforts; guarantee the availability and affordability of resources in Mental Health Efforts; improve the quality of Mental Health Efforts in accordance with the development of science and technology; and provide opportunities for ODMK and ODGJ to be able to exercise their rights and obligations as Indonesian citizens.

The Law on Mental Health contains general provisions; Mental Health Efforts; Mental health service system; resources in Mental Health Efforts; rights and obligations; Mental Health examination; duties, responsibilities, and authority; community participation; criminal provisions and closing provisions. Based on the description above, there is a gap between the implementation of mental health efforts in Depok City and Law Number 18 of 2014 concerning Mental Health. The magnitude of this mental health problem is not yet considered as the main thing in health care programs (WHO, 2017). The partiality of the Regional Government of Depok City towards mental health efforts is still limited. The health system in Depok City still shows low investment in mental health, for this reason it is necessary to strengthen the implementation of mental health efforts so that they are not neglected and receive the same priority as other health programs towards the realization of Depok City Healthy, both physically, mentally and socially (DHO) (City of Depok, 2017). 


\section{SUBJECTS AND METHOD}

\section{Study Design}

This was a qualitative study with a descriptive exploration approach.

\section{Study Informant}

The informants in the study were Depok City government employees who were selected by purposive sampling. The data obtained from document studies include the 2013 Riskesdas survey, the Depok Health Profile in 2016 and 2017, the results of WHO activities reports, previous studies on mental health, and related regulations and policies.

\section{Data collection techniques and analysis}

The data collection was conducted by depth-interview techniques. The input data were in the form of man, money, material, method, and machine. The process of data management and outcome data is obtained through a review document.

\section{RESULTS}

1. Problems of Efforts for Mental Health Services in Depok City

Mental health efforts in Depok City have not been optimal and seem to be still neglected. This is because the Regional Government of Depok City has not carried out its duties, responsibilities and authorities in accordance with the directions of the Mental Health Act based on Chapter VIII, Article $75-83$.

a. Duties, responsibilities and authorities.

This is described as conducting communication, information, and education about community mental health in a comprehensive and sustainable manner, must coordinate with stakeholders and be organized by involving the community participation. The condition in Depok is presented as follows: (1)
The unavailability of specific policies on mental health efforts and the establishment of the Depok City Level Mental Health Implementation Team (TPKJM) which refers to the Decree of the Minister of Health of the Republic of Indonesia number 220/Menkes /SK/III/2002; (2) The absence of community participation to carry out preventive and promotive efforts and early detection of mental disorders and undertake efforts to rehabilitate and reintegrate Mental Disorders (ODGJ) into the community; (3) The unavailability of fast and easy tools for screening mental health disorders in the community; (4) Not optimal recording and reporting of cases of mental health disorders.

b. Providing facilities and infrastructure in the implementation of Mental Health Efforts.

The condition in Depok is presented as follows: (1) Unavailability of inpatient facilities for patients with mental disorders in Depok Public Hospital; (2) Unavailability of service facilities outside the health sector and community-based service facilities which include: a) the practice of psychologists; b) practice of social workers; c) social homes; d) social welfare center; e) social rehabilitation center; f) social protection house; g) Islamic boarding schools/ religious institutions; h) halfway house; and i) social welfare institution; (3) Not enough budget support for Mental Health Efforts activities which is $<50$ million rupiah / year

c. Ensuring the availability and welfare of human resources in the field of Mental Health.

The condition in Depok is presented as follows: (1) Psychiatrists have not been adequate, only 2 (two) people are assigned to the hospital owned by the Government and Regional Government; (2) 
The lack of efforts to improve the competence of health workers in terms of screening and mental health services in FKTP.

d. Setting the availability of psych pharmaceutical drugs needed by ODGJ according to standards that are available evenly throughout Depok City at affordable prices by the community and carried out by involving the private sector. The situation in Depok for this sector is quite adequate.

e. Management of ODGJ who are neglected, vandalized, threatens the safety of themselves and/ or others, and/ or disturbs public order and/ or security.

The condition in Depok was presented as follows: (1) There is no clear SOP regarding the handling of ODGJ that is neglected, vandalized, threatens the safety of himself and/ or other people, and/ or disturbs public order and/ or security and involves Cross-Programming and Cross-Sector. (2) There is already a Health Financing Guarantee available for ODGJ who are abandoned and homeless.

f. Making efforts to rehabilitate ODGJ neglected, vandalize, threaten the safety of themselves and/ or other people, and/ or disturb public order and/ or security, including ODGJ: a. unable; b. do not have a family, guardian or guardian; and/ or c. unknown to his family.

The condition in Depok was presented as follows: The unavailability of service facilities outside the health sector and community-based service facilities which include: (1) The practice of psychologists; (2) Practice of social workers; (3) Social homes; (4) Social welfare center; (5) Social rehabilitation center; (6) Social protection house; (7)
Islamic boarding schools/ religious institutions; (8) Halfway house; and (9) Social welfare institution

g. Shelter in service facilities outside the health sector for ODGJ who have recovered or are controlled by symptoms that have no family and/ or are displaced.

The condition in Depok was presented as follows: The unavailability of service facilities outside the health sector and community-based service facilities which include: (1) The practice of psychologists; (2) Practice of social workers; (3) Social homes; (4) Social welfare center; (5) Social rehabilitation center; (6) Social protection house; (7) Islamic boarding schools/ religious institutions; (8) halfway house; and (9) social welfare institution.

\section{Implementation of Mental Health Efforts}

The determination of Law No. 18 of 2014 concerning Mental Health brings a new direction towards mental health efforts in Indonesia, this Law requires that every element of government, both central and regional, beginning to implement mental health efforts. The mandatory application of mental health efforts is also an obligation in accordance with the mandate of Government Regulation Number 2 of 2018 concerning Minimum Service Standards (SPM) and also Minister of Health Regulation number 43 of 2016 concerning Health MSS, which is on the 1oth indicator, namely health services for people with severe mental disorders (Ministry of Health, 2016; Regulation President of the Republic of Indonesia, 2018).

Mental Health Efforts are every activity to realize optimal mental health degrees for every individual, family, and community with a promotive, preventive, curative, and rehabilitative appro- 
ach that is carried out in a comprehensive, integrated and sustainable manner by the Government, Regional Government, and/ or the community. Based on Law Number 18 of 2014 concerning Mental Health Article 3, it is stated that Mental Health Efforts aiming at:

a. Ensuring that everyone can achieve a good quality of life, enjoy a healthy raw life, free from fear, pressure, and other disorders that can interfere with Mental Health;

b. Ensuring that everyone can develop various intelligence potentials;

c. Providing protection and ensuring mental health services for ODMK and ODGJ based on human rights;

d. Providing integrated, comprehensive and sustainable health services through promotive, preventive, curative and rehabilitative efforts for ODMK and ODGJ;

e. Ensuring the availability and affordability of resources in Mental Health Efforts;

f. Improving the quality of Mental Health Efforts in accordance with the development of science and technology; and;

g. Providing opportunities for ODMK and ODGJ to obtain their rights as Indonesian citizens.

The achievement of mental health efforts as described above will not be achieved if the implementation of mental health efforts by the Government and Regional Government is not in line with the directions mandated in the Mental Health Act, namely to carry out overall promotive, preventive, curative and rehabilitative efforts. Based on the literature review and in-depth interviews with the Depok City Health Office, it was found that mental health service efforts in Depok City have not run optimally, this can be seen from:

a. Promotive efforts

Mental Health Act Article 8 states promotive efforts are carried out in the environment: (1) Family; (2) Educational institutions; (3) Workplace; (4) Community; (5) Health service facilities; (6) Media; (7) Religious institutions and places of worship; and h. correctional facilities and detention centers. In this promotive effort, the city of Depok is only reaching out to family, community and health service facilities, while other programs have not been reached.

b. Preventive Efforts

Mental Health Act Article 12 states that preventive measures for mental health are carried out in the following areas: a. family; b. institution; and c. society. In this preventative effort, Depok City has only reached the family environment, but the institutional environment and community environment have not been optimal.

\section{c. Curative Efforts}

Mental Health Act Article 18 states Curative efforts for Mental Health are aimed at healing or recovery, reducing suffering, controlling disability and controlling symptoms of the disease. In this Curative Effort, Depok City does not yet have inpatient services that can cover all curative efforts.

\section{d. Rehabilitation efforts}

Mental Health Act Article 25 states that Rehabilitation of Mental Health is an activity and/ or a series of Mental Health service activities aimed at: (1) Prevent or control disability; (2) Restore social function; (3) Restore occupational functions; and preparing and giving ODGJ the ability to be independent in the community. In this rehabilitation effort, Depok does not yet 
have the resources to implement the program.

\section{Authority}

Government Mental Health Efforts authorized: Holding and utilizing human resources in the field of Mental Health who will work in service facilities in the field of Mental Health; and supervising the implementation of Mental Health Efforts and resources in Mental Health Efforts. From the authority outlined above, the Depok City Government has not optimally implemented the authority mandated to carry out mental health efforts.

\section{DISCUSSION Causes}

Depok City with a population in 2014 reached 2,033,508 mentally, consisting of $1,025,784$ mental men (50.44\%) and 1,007,724 mental women (49.56\%), and geographically, Depok City borders directly with the City of Jakarta or within the Jabotabek area and become the buffer zone of the capital. Based on these conditions, Depok City faces challenges and health problems, one of which is mental health. Analysis of the causes of neglected mental health efforts in Depok City are as follows:

\section{a. Man (Human Resources)}

Health resources, especially in the field of mental health efforts are still limited. Based on health profile data and the 2015 Depok City Mental Health Program Activity Report is presented as follows: (1) Mental specialist doctors: 5 people practicing in Depok City; (2) Trained General Physicians Mental Health: 35 people; (3) Trained Mental Health nurse: 35 people; (4) Trained Health Cadre Mental Health: 63 people. The limitations of this human resource, both in number and competence, are one of the causes of poor mental health efforts (Depok City Health Office, 2017; Depok City Health Office, 2018; Ministry of Health, 2018)

\section{b. Money (Source of funds)}

Mental health programs are still integrated with special health programs, so the budget allocated for the activities is still limited. Since the last 5 years, indicators of mental health efforts have not been included in the Depok City RPJMD, so budget allocations are limited. The total budget allocation is only around 50-70 million Rupiah per year. This limited budget allocation makes mental health programs not optimal in driving program support.

\section{c. Material}

Supporting infrastructure facilities for mental health efforts are limited, both health facilities and non-health facilities. This happened, because Depok City, which was 16 years old, was still at the stage of infrastructure development, the facilities of the Hospital belonging to the Regional Government were still limited. There are no special inpatient facilities for people with mental disorders.

\section{d. Method}

Program management is still done manually, both data management and complaints and complaints services. Media public complaints or reporting ODGJ cases found in the community are not yet available, management of morbidity data in both FKTP and FKRTL is not optimal and does not cover all cases that have occurred in Depok City. This happens because the limitations of human resources who understand information technology are still limited, inadequate supporting facilities and cross-program and crosssector cooperation are not optimal.

\section{e. Machine}


The driving force for mental health programs is largely determined by the collaboration between Cross Programs and Cross-Sector and strengthening community empowerment. If this mental health effort is completely handed over to health workers, it prolongs health problems. Empowerment of health cadres at every opportunity to carry out promotive and preventive efforts, in addition to by religious staff is a technique that is strategic in responding to various shortcomings possessed.

\section{Alternative Mental Health Strengthening Program in Depok}

The paradigm of strengthening mental health is currently undergoing changes, prevention aspects and the role of the community in helping empower people with mental disorders are preferred (WHO, 2011). Strengthening the mental health effort program cannot be separated from the paradigm. Based on the problems of mental health efforts, which have been described through the techniques above, the following alternative strategies for strengthening mental health efforts in Depok City based on pardigms prioritize prevention and the role of the community, namely: Unite, Find, Healthy, Empower

\section{a. Unite}

All stakeholders, both across programs and across sectors, strengthen policy support for mental health efforts, including drafting Regional Regulations / Mayor Regulations on mental health efforts, forming TPKJM and empowering all stakeholders to be actively involved up to the Household setting and provide financial support.

Leading sector, namely the Department of Health united with Puskesmas and hospitals, both private and government supports the implementa- tion of mental health services, ranging from health promotion, screening and handling programs to training health and non-health human resources, making referral channels, handling emergencies, providing medicines medicine needed and preparation of inpatient facilities, non-health facilities and management of integrated recording and reporting.

\section{b. Find}

All stakeholders, both across programs and across sectors, strengthen policy support for mental health efforts, including drafting Regional Regulations / Mayor Regulations on mental health efforts, forming TPKJM and empowering all stakeholders to be actively involved up to the Household setting and provide financial support.

Leading sector, namely the Department of Health united with Puskesmas and hospitals, both private and government supports the implementation of mental health services, ranging from health promotion, screening and handling programs to training health and non-health human resources, making referral channels, handling emergencies, providing medicines needed and preparation of inpatient facilities, non-health facilities and management of integrated recording and reporting.

\section{c. Healthy}

Conducting treatment according to the standard of therapy in FKTP, especially emergency and fulfillment of the medicines needed and the referral program from the Hospital to FKTP; Preparing ODGJ inpatient facilities at RSUD Kota Depok; Establishing mental health care groups that can provide support for families with ODGJ; Providing health insurance support for residents with criteria that cannot 


\section{d. Empower}

Establishing a social institution for rehabilitation to controlled ODGJ. Empowering communities and the private sector by opening job opportunities, especially SMEs for controlled ODGJ so that they remain useful, not only for themselves but also for others.

The results of studies and indepth interviews show that mental health efforts in Depok City have not been optimal, promotive, preventive, curative and rehabilitative. This can be seen from the Duties, Responsibilities and Authorities of the Depok City Government based on Law Number 18 Year 2014 concerning duties, responsebilities and authorities that have not been implemented optimally. Resources in Mental Health Efforts consisting of human resources in the field of Mental Health, service facilities in the field of Mental Health, Mental Health supplies, technology and technology products for Mental Health and Mental Health funding are problems that the Depok City government must overcome. "United, Discover, Healthy and Empower" can be an alternative program to strengthen mental health service efforts in Depok City.

The recommendation for the Depok City Government is to implement an alternative mental health service strengthening program that prioritizes the community prevention and empowerment paradigm so that mental health problems in Depok City can be resolved, in addition to making regulations or policies that are the basis for implementing these strengthening efforts.

\footnotetext{
REFERENCE

Dewi KS (2012). Buku Ajar Kesehatan Mental. Semarang: Lembaga Pe-
}

ngembangan dan Penjamin Mutu Pendidikan, Universitas Diponegoro.

Depok Health Office (2016). Tabel Profil Kesehatan Kota Depok.

Depok Health Office (2018). Profil Kesehatan Kota Depok 2017.

Depok Health Office (2017). Profil Kesehatan Kota Depok Tahun 2016. Available at: http://dinkes.depok.go.id/.

Ministry of Health (2015). Rencana Strategis Kementrian Kesehatan RI tahun 2015-2020.

Ministry of Health (2018). Profil Kesehatan Indonesia 2017.

Ministry of Health (2013). Laporan Riskesdas 2013.

Ministry of Health (2016). Peraturan Menteri Kesehatan Nomor 43 tahun 2016 tentang Standar Pelayanan Minimal (SPM) Bidang Kesehatan. Indonesia.

Republic Indonesia (2014). UndangUndang Nomor 18 Tahun 2014 tentang Kesehatan Jiwa. Indonesia.

President Regulation of Republic Indonesia (2018). Peraturan Pemerintah Nomor 2 Tahun 2018 tentang Standar Pelayanan Minimal (SPM). Indonesia.

Siswanto (2007). Kesehatan Mental: Konsep, Cakupan dan Perkembangan. Yogyakarta: Penerbit Andi.

WHO (2004). Prevention of Mental Disorder, Effective Intervention and Policy Option. Geneva.

WHO (2011). Strengtening Mental Health System through Community-based Approach. New Delhi.

WHO (2013). Mental Health Action Plan 2013-2020. Geneva.

WHO (2014a). Global Mental Heath Atlas Country Profile 2014. Geneva. 
WHO (2014b). Word Health Statistic.

WHO (2017). Depression and Other
Common Mental Disorder, Global Health estimetes. Geneva. 